\title{
Implementasi Pendekatan Values Clarivication Technique (VCT) dalam Pembelajaran IPS Sekolah Dasar
}

\author{
AGUSTINA TRI WIJAYANTI \\ Jurusan Pendidikan IPS FIS UNY \\ e-mail : Agustina1044@gmail.com
}

\begin{abstract}
Abstrak
Penelitian bertujuan untuk mengimplementasikan pendekatan Values Clarification Technique (VCT) dalam pembelajaran IPS di SD Sekarsuli, Banguntapan, Bantul, Yogyakarta. Menggunakan metode kualitatif deskriptif, subjek penelitian siswa kelas V. Pengumpulan data melalui observasi, wawancara, catatan lapangan dan analisis dokumen. Analisis data secara kualitatif dengan teknik yang dikembangkan Miles dan Huberman. Hasil penelitian menunjukkan bahwa dengan penerapan teknik klarifikasi nilai, proses pembelajaran IPS semakin bermakna. Guru mudah untuk menyampaikan materi dan menanamkan nilai karakter pada siswa. Implementasi pembelajaran dilakukan dengan mengklarifikasi dan menginternalisasi nilai-nilai karakter yang disesuaikan dengan materi, menerapkan model tanya jawab, cerita anak secara konstekstual, analisis kasus serta diskusi kelompok untuk melatih kerjasama, saling menghargai dan memahami orang lain. Hasil Implementasi Values Clarification Technique (VCT) dalam Pembelajaran IPS memunculkan perilaku positif siswa seperti aspek nilai religius dan taat beribadah, toleransi terhadap sesama, disiplin, kepedulian terhadap teman, bermusyawarah dan tanggung jawab dalam menyelesaikan tugas tepat waktu baik individu maupun kelompok.
\end{abstract}

Kata kunci : Values Clarification Technique (VCT), Pembelajaran IPS

\begin{abstract}
The research aims at implementing the Values Clarification Technique (VCT) in Social Studies Learning at Elementary school of Sekarsuli, Banguntapan, Bantul, Yogyakarta. This research used descriptive qualitative method. The subjects of the research were students of class $V$. The data were collected through observation, interviews, field notes and document analysis. Data analysis was performed with qualitative techniques developed by Miles and Huberman. The results show that the application of Values Clarification Technique (VCT) make Social Studies more meaningful. Teacher could deliver Social Studies material and instill the values of good character in students easily. The implementation of the technique was performed by clarifying and internalizing the values and characters that suits with the Social Studies subject matter using questions and answers techniques; contextual kids stories; case analysis; and group discussion to practice cooperation, mutual respect and understanding of others. The implementation of Values Clarification Technique (VCT) in Social Studies could bring positive behavior for the students such as religious and pious values, tolerance for others, discipline, care with friends, deliberation and responsibility in completing the task on time both individuals and groups.
\end{abstract}

Keywords : Values Clarification Technique (VCT), Social Studies 


\section{PENDAHULUAN}

Melihat permasalahan kondisi Indonesia dewasa ini, masalah uang, kedudukan, pangkat, kekuasaan selalu didewakan dan dipentingkan sehingga banyak terjadi pergeseran nilai yang tumbuh di masyarakat seperti perubahan nilai-nilai sosial, ekonomi dan kekuasaan. Permasalahan tentang pergeseran nilai-nilai dalam masyarakat tersebut dapat diatasi dengan menelaah berbagai kemungkinan pemecahan masalah, salah satunya adalah melalui pendidikan.

Sesuai dengan tujuan pendidikan (UU No. 20 Tahun 2003) yaitu mewujudkan suasana belajar dan proses pembelajaran agar peserta didik secara aktif dapat mengembangkan potensi dirinya untuk memiliki kekuatan spiritual keagamaan, pengendalian diri, kepribadian, kecerdasan, akhlak mulia serta keterampilan yang diperlukan dirinya, masyarakat, bangsa dan negara. Sehubungan dengan tujuan pendidikan tersebut, peme rintah berupaya untuk meningkatkan kualitas pendidikan agar dapat menghasilkan sumber daya manusia yang cerdas, berkualitas, berkarakter dan berbudaya.

Peningkatan kualitas sumber daya manusia dapat ditempuh melalui perbaikan sistem pendidikan yang mengarah pada pembentukan karakter siswa sejak tingkat pra sekolah sampai perguruan tinggi. Pembentukan karakter sebagai upaya meningkatkan perilaku siswa dilaksanakan secara berkesinambungan yang melibatkan aspek knowledge, feeling, dan acting (Tadkiroatun Musfiroh, 2008: 31). Tetapi yang terjadi sekarang adalah pola pendidikan yang masih berorientasi pada pengembangan aspek kognitif dan kurang memperhatikan pengembangan aspek afektif, dan psikomotorik. Mata pelajaran yang berkaitan dengan pendidikan karakter pada prakteknya lebih menekankan pada aspek kognitif tingkat rendah (hanya sekedar tahu saja). Selain itu, sistem pendidikan yang terfokus pada aspek kognitif bersifat abstrak, serta diikuti dengan proses belajar siswa yang pasif, kaku, dan kurang menyenangkan.
Dari hasil observasi di kelas nampak siswa kurang bersungguh-sungguh dalam berdoa baik sebelum atau sesudah pelajaran. Indikasinya adalah dalam membaca doa, siswa sambil melihat kanan kiri, posisi duduk siswa saling berhimpitan dan siswa membentuk kelompok bermain sendiri, dan kurang bertanggung jawab dengan tugasnya sebagai siswa. Selain itu, dalam proses pembelajaran siswa terlihat kurang memperhatikan penjelasan guru, asyik berbicara dengan teman sampingnya, mentertawakan jawaban teman yang salah, kurang tepat waktu dalam menyelesaikan tugas baik individu maupun kelompok, piket harian belum berjalan se suai jadwal yang ditetapkan, dan kurangnya kerjasama antar siswa.

Sejalan dengan permasalahan di atas, perlu adanya penerapan pembelajaran yang baik melalui pengintegrasian nilai-nilai karak ter dalam proses pembelajaran IPS. Untuk itu perlu dikembangkan model pembelajaran berbasis karakter melalui klarifikasi nilai-nilai karakter atau pendekatan values clarification technique (VCT) yang melibatkan partisipasi aktif siswa, dengan permasalahan yang konkrit dan bermakna.

Melalui penerapan teknik klarifikasi nilai (VCT) diharapkan siswa dapat memilih, memutuskan, mengkomunikasikan, mengungkapkan keyakinan, memecahkan masalah serta mempunyai pendirian dalam mengambil keputusan, sehingga mampu menginternalisasikan dan berperilaku sesuai dengan nilai-nilai yang telah dipilih dan diyakini. Dengan pengintegrasian nilai-nilai karakter (ketaatan beribadah, toleransi, kepedulian, dan tanggung jawab) melalui penerapan teknik klarifikasi nilai dalam pembelajaran IPS harapannya semua dimensi intelektual, kreatifitas, fisik, sosial-emosi dan spiritual lebih optimal. Orientasi pembelajaran IPS adalah mewujudkan perilaku manusia se utuhnya serta mampu menghadapi segala persoalan dan tantangan hidup di masyarakat.

\section{Pengertian Teknik Klarifikasi Nilai}

Wina Sanjaya (2008: 283) menjelaskan 
bahwa teknik klarifikasi nilai atau sering disebut dengan values clarification technique dapat diartikan sebagai teknik pembelajaran untuk membentuk siswa dalam mencari dan menentukan suatu nilai yang dianggap baik dalam menghadapi suatu persoalan melalui proses menganalisis nilai yang sudah ada dan tertanan dalam diri siswa. Hall (1973: 11) mengartikan values clarification technique:

"By value clarification we mean methodology or process by which we help a person to discover values through behavior, feelings, ideas and trough important choices he has made and is continually in fact, acting upon in and trough his life"

Pernyataan tersebut menekankan bahwa values clarification technique merupakan metode klarifikasi nilai dimana siswa tidak disuruh menghafal dengan nilai yang sudah dipilihkan tetapi dibantu untuk menemukan, memilih, menganalisis, mengembangkan, mempertanggungjawabkan, mengambil sikap dan mengamalkan nilai-nilai kehidupannya sendiri.

Beberapa model pendidikan afektif menurut Nasution (2006: 163) seperti; model konsiderasi untuk mengembangkan kepribadian siswa menjadi manusia yang otentik dan kreatif; model pembentukan rasional diterapkan untuk mengajarkan nilainilai dasar yang berlaku dalam masyarakat model values clarification atau klarifikasi nilai dimaksudkan untuk membantu siswa untuk menganalisis dan memilih nilai secara bebas yang dianggapnya baik. Sebagai contoh mo del pembelajaran dalam rangka menanamkan karakter siswa adalah values clarification technique yang merupakan teknik klarifikasi nilai dimana siswa tidak menghafal dengan nilai-nilai yang dipilihkan tetapi siswa dibantu menemukan, menganalisis, mempertanggungjawabkan dan mengembangkan nilai hidupnya sendiri mana yang baik dan benar.

Wina Sanjaya (2008: 284), model klarifikasi nilai merupakan salah satu teknik pembelajaran yang dapat memenuhi tujuan pencapaian pendidikan nilai dan merupakan cara bagaimana menanamkan dan menggali atau mengungkapkan nilai-nilai tertentu dari diri siswa. Pada prosesnya teknik klarifikasi nilai berfungsi untuk: a) mengukur atau mengetahui tingkat kesadaran siswa tentang suatu nilai; b) membina kesadaran siswa tentang nilai-nilai yang dimilikinya baik yang positif maupun yang negatif untuk kemudian dibina kearah peningkatan atau pembetulannya; c) menanamkan suatu nilai kepada siswa melalui cara yang rasional dan diterima siswa sebagai milik pribadinya. Barth (1990: 371) menjelaskan bahwa pendekatan klarifikasi nilai yaitu:

Values clarification approach, a teaching strategy which is used to focus on the process of valuing rather than the content of values. It attempts to help students answer questions about how values are formed and to develop their own values system.

\section{Model Klarifikasi Nilai}

Simon (1972: 15) menggolongkan bebe rapa model klarifikasi nilai sebagai berikut:

- Moralizing is the direct, although sometimes subtle, inculcation of the adult's values upon the young.

- Some adults maintain a laissez-faire attitude toward the transmission of values.

- Modeling is a third approach in transmitting values.

- The values-clarification approach tries to help young people answer some of these questions and build their own value system.

Dalam proses pembelajaran IPS, teknik klarifikasi nilai dapat diterapakan dengan menggunakan metode pembelajaran seperti inquiry, diskusi kelompok, cooperative learning, analisis dilema moral, moral problem solving, presentasi dalam kelompok besar maupun kecil, ceramah dan tanya jawab. Teknik klarifikasi nilai memberi penekanan pada pemilihan dan penentuan nilai secara bebas serta sikap terhadapnya.

Teknik klarifikasi nilai mempunyai kelebihan untuk melatih siswa mengkomunikasi kan keyakinan, nilai hidup, cita-cita pribadi pada teman sejawat, berlatih berempati pada teman yang mungkin berbeda keyakinan, berlatih memecahkan persoalan dilema moral, berlatih untuk 
setuju atau menolak keputusan kelompok, berlatih terlibat dalam membuat keputusan ataupun mempertahankan keyakinannya. Selain kelebihan terdapat pula beberapa kelemahan yang sering terjadi dalam proses pembelajaran nilai seperti proses pembelajaran yang dilakukan secara langsung oleh guru artinya guru menanamkan nilai-nilai yang dianggap baik tanpa memperhatikan nilai yang tertanam dalam diri anak, akibatnya sering terjadi benturan konflik dalam diri siswa. Maka dari itu, teknik klarifikasi nilai menjadi alternative strategi sebagai proses penanaman nilai yang dilakukan melalui proses analisis nilai yang sudah ada sebelumnya pada diri siswa kemudian diselaraskan dengan nilai baru yang akan ditanamkan.

Teknik klarifikasi nilai apabila diterapkan dalam pembelajaran maka dapat meningkatkan kemampuan siswa untuk: 1) memilih, memutuskan, mengkomunikasikan, mengungkapkan gagasan, keyakinan, nilainilai dan perasaannya; 2) berempati atau memahami perasaan orang lain dan melihat sudut pandang orang lain; 3) memecahkan masalah; 4) menyatakan sikap setuju atau tidak setuju, menolak atau menerima pendapat orang lain; 5) mempunyai pendirian dalam mengambil keputusan, menginternalisasikan dan bertingkah laku sesuai dengan nilai yang telah dipilih dan

Gambar 7.

Langkah-langkah pembelajaran dengan metode VCT dalam 7 tahap dan 3 tingkat.

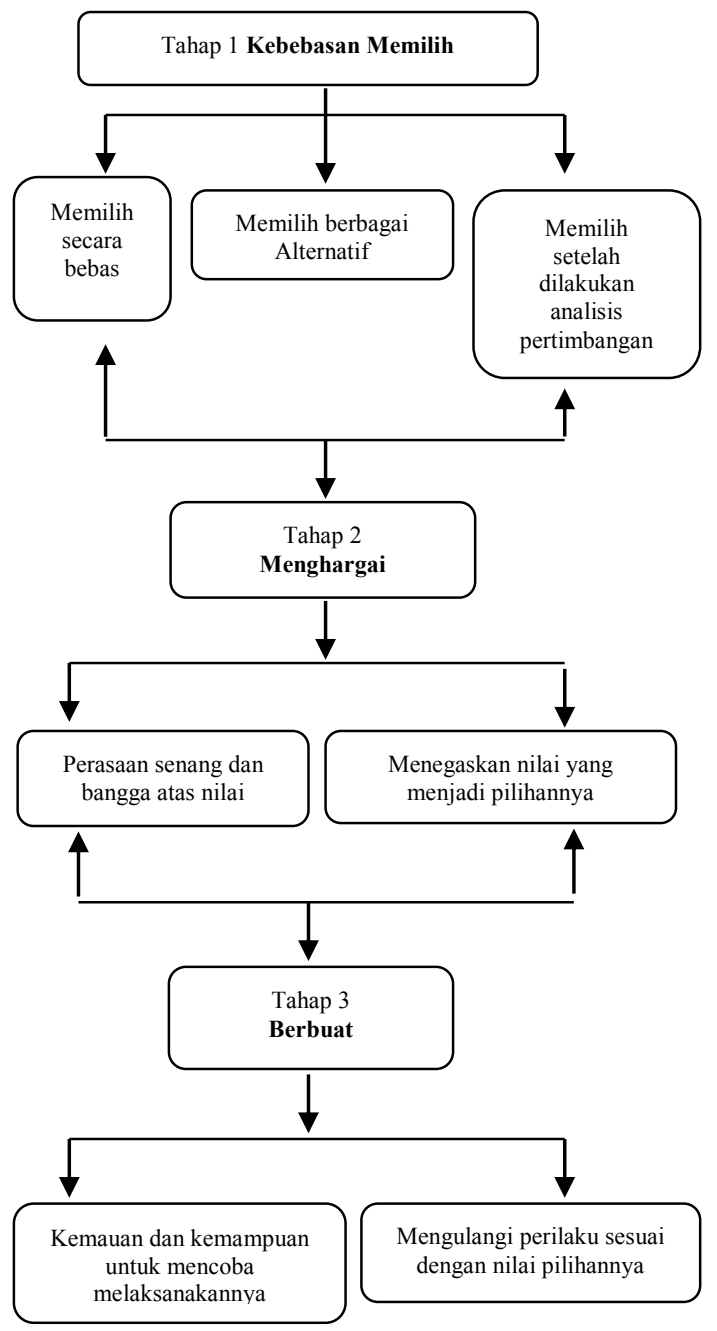


diyakini. Langkah-langkah pembelajaran dengan metode VCT dalam 7 tahap yang dibagi ke dalam 3 tingkat dijelaskan di samping ini:

\section{Pengertian IPS}

National Council for Social Studies (NSCC) mendefinisikan Ilmu Pengetahuan Sosial sebagai berikut:

Social studies as "the integrated study of the social science and humanities to promote civic competence". Within the school program, social studies provides coordinated, systematic, study drawing upon such disciplines as anthropology, archeology, economics, geography, law, philosophy, political science, psychology, religion and sociology, as well as appropriate content from the humanities, mathematic and natural sciences. (Savage, 1996: 9)

Melalui pembelajaran Ilmu Pengetahuan Sosial, siswa diajarkan untuk menjadi warga negara Indonesia yang baik dan penuh kedamaian. Ilmu Pengetahuan Sosial diperlukan bagi keberhasilan transisi kehidupan menuju pada kehidupan yang lebih dewasa dalam upaya membentuk karakter bangsa yang sesuai dengan prinsip dan semangat nasional. Dengan demikian para siswa dalam pembelajaran IPS terlatih untuk menyelesaikan persoalan sosial dengan pendekatan secara holistik dan terpadu dari berbagai sudut pandang.

\section{Tujuan IPS}

Ilmu Pengetahuan Sosial merupakan mata pelajaran yang diberikan mulai dari pendidikan dasar, Ellis (1997: 6) menjelaskan tujuan pembelajaran IPS adalah:

"Social studies is designed to help children explain their world. By organization he basically meant the ability to understand and classify things with respect to how they work. Adaptation refers to the process of accommodating one self to one's environment. A child who enters school has already adapted considerably to the environment through speech, dress, rules at home, and so forth but school is designed to expand such adaptation greatly through formal learning processes, social, emotional, and physical. "(Savage, 1996)

Sardjiyo (2007: 28) menjelaskan bahwa tujuan pendidikan IPS di SD sesuai dengan tujuan kurikuler yang merupakan penjabaran dari tujuan institusional dan tujuan Pendidikan Nasional adalah sebagai berikut:

- Membekali siswa dengan pengetahuan sosial yang berguna dalam kehidupan di masyarakat.

- Membekali siswa dengan kemampuan mengidentifikasi, menganalisis dan menyusun alternatif pemecahan masalah sosial yang terjadi di masyarakat.

- Membekali siswa dengan kemampuan berkomunikasi dengan sesama warga masyarakat.

- Membekali siswa dengan kesadaran, sikap mental yang positif dan keterampilan terhadap pemanfaatan lingkungannya.

Tujuan yang lain adalah membentuk sikap yang diperlukan untuk tingkah laku berfikir (intellectual behavior) dan tingkah laku sosial (social behavior). Tujuan-tujuan tersebut bermuara pada tujuan utama IPS yaitu untuk melatih siswa untuk bertanggung jawab sebagai warga negara yang baik serta mempersiapkan generasi muda untuk menjadi seorang humanis, rasional, berpartisipasi dalam kehidupan dunia dan menjadi meningkat kesadaran untuk saling membutuhkan dalam hidupnya.

\section{METODE}

Penelitian ini menggunakan metode kualitatif deskriptif, sifat penelitian kualitatif deskriptif berarti penelitian kualitatif yang selalu menyajikan temuannya dalam bentuk deskripsi kalimat yang rinci, lengkap, dan mendalam mengenai proses pembelajaran IPS menggunakan penerapan VCT. Teknik pengumpulan data yang digunakan dalam penelitian ini adalah wawancara, observasi langsung berperan pasif, dan analisis dokumen. Teknik analisis data yang digunakan untuk mencari validitas data adalah menggunakan teknik trianggulasi. Penelitian ini menggunakan teknik trianggulasi data dan 
trianggulasi metode.

\section{HASIL DAN PEMBAHASAN}

Pembelajaran IPS pertemuan pertama membahas tentang keragaman suku budaya dan persebaran suku bangsa di Indonesia. Sesuai dengan perencanaan, materi yang disajikan pada pertemuan pertama melalui metode ceramah dan demontrasi. Guru memulai pelajaran dengan berdoa dipimpin oleh ketua kelas, kemudian guru memberikan apersepsi dengan memberikan semangat dan motivasi kepada siswa. Setelah apersepsi, guru menjelaskan materi tentang persebaran suku dan budaya di Indonesia. Guru menanyakan pada siswa tentang gambar suku apa yang mereka temukan di buku. Kemudian guru mengklarifikasi nilai-nilai yang termuat dalam keanekaragaman budaya Indonesia seperti saling menghormati, menghargai, dan mengakui suku budaya lain.

Metode yang digunakan guru pada pertemuan pertama ini mampu menunjukkan keaktifan mereka melalui pertanyaan-perta nyaan yang diberikan guru. Tanya jawab yang dilakukan guru pada awal pembelajaran IPS untuk nilai ketaatan beribadah dan toleransi seperti berikut:

"Sebutkan ada berapa agama yang ada di Indonesia? Apa yang kalian akan lakukan apabila teman kalian yang berbeda agama sedang menjalankan ibadah?"

Guru menanyakan kembali tentang sikap yang dilakukan pada saat teman yang berbeda agama melaksanakan ibadah pada saat kalian belajar bersama. Siswa tidak ada yang tunjuk tangan, kemudian guru menunjuk satu siswa untuk menjawab. Jawaban salah satu siswa, "tidak mengganggu, bu". Kemudian guru mengklarifikasi jawaban siswa. Jawa ban teman kalian benar, kalian tidak boleh mengganggu apalagi berbicara keras-keras. Dengan begitu kalian bisa saling menghormati dan menghargai antar teman yang berbeda agama.

Pertemuan selanjutnya materi tentang keragaman suku dan budaya di Indonesia. Pada pertemuan kedua metode yang diguna kan guru adalah diskusi dengan teman seme- ja, setiap kelompok menyampaikan nilainilai beserta pertanyaan kritis yang terkait dengan nilai dalam cerita. Kemudian masingmasing siswa menanggapi pertanyaan terhadap nilai, setelah itu setiap kelompok teman semeja mencoba merangkum pendapat bersama dan mengutarakan pilihan-pilihan nilai beserta alasannya. Siswa berlatih untuk mendengarkan, menyimak penjelasan dan cerita yang disampaikan guru. Siswa mempunyai kebebasan memilih alternatif nilai yang di sampaikan dengan disertai alasannya. Peran guru sebagai fasilitator, memberikan perta nyaan kritis terhadap pendapat siswa tanpa memaksa. Metode yang diterapkan dapat memberikan siswa kesempatan untuk berpendapat dan menanggapi nilai-nilai yang ditemukan dalam cerita "berbeda tetap satu jua". Guru menjelaskan apa saja yang harus dilakukan siswa untuk menyelesaikan cerita tersebut.

Penyampaian materi tentang keragaman suku dan budaya di Indonesia dengan cerita anak mempermudah siswa dalam memahami materi dan juga siswa belajar mengkaitkan materi dalam kehidupan sehari-hari. Setelah diskusi siswa selesai, guru menunjuk perwakilan siswa untuk membacakan jawabannya. Beberapa hasil diskusi siswa menunjukkan bahwa isi dalam cerita adalah sikap yang baik, bangga terhadap budaya Indonesia, senang karena memakai pakaian adat Indonesia, dan gembira karena bisa ikut perlombaan pakaian adat. Setelah berdiskusi, salah satu siswa bertanya, "bu, kapan sekolah kita menyelenggarakan lomba pakaian adat?". Biasanya setiap hari Kartini, semua siswa pada hari itu mengenakan pakaian adat, acara tersebut untuk mengenang "Ibu Kartini”, jawab guru. Kemudian guru mengklarifikasi nilai-nilai dari hasil diskusi siswa:

Semua jawaban yang kalian sampaikan tidak ada yang salah, nilai yang terkandung dalam isi cerita diantaranya sudah kalian sebutkan, seperti bangga terhadap budaya bangsa, bisa menghargai budaya bangsa, yang lebih penting lagi bahwa kalian dapat mengenal dan memahami keberagaman budaya Indonesia. Untuk itu, kalian harus saling menghormati dan juga menghargai antar te- 
man yang berbeda suku, agama dan budaya.

Materi selanjutnya tentang menghormati budaya bangsa Indonesia, metode yang digunakan adalah pertanyaan kasus yang diberikan oleh guru. Hal ini dimaksudkan agar siswa mampu memberikan keputusan moral yang akan mereka ambil tentang sikap apa saja yang perlu kita kembangkan untuk menghargai perbedaan-perbedaan tersebut. Guru menjelaskan pada siswa, apa yang harus siswa lakukan untuk menyelesaikan tugas pada pertemuan ini. Guru memberikan pertanyaan tentang sikap apa yang perlu kalian kembangkan untuk menghargai kebera gaman suku dan budaya Indonesia? Kemudian, apa akibatnya apabila kalian tidak dapat menghargai keberagaman budaya tersebut?

Guru memberikan pertanyaan tentang sikap apa saja yang perlu kita kembangkan untuk menghargai perbedaan suku dan budaya dan akibat apa yang akan kita terima apabila kita tidak menghargai budaya lain. Guru memberikan kesempatan pada siswa untuk memutuskan alternatif jawaban menurut mereka mana yang baik dan yang tidak baik dan apa yang harus kita lakukan. Di akhir proses pembelajaran guru mengklarifikasi nilai-nilai yang diputuskan siswa, serta memberikan keputusan nilai moral yang baik agar siswa dapat menerapkan dalam perilaku sehari-hari seperti saling menghormati, menghargai dan saling membantu satu sama lain.

Dari pelaksanaan proses pembelajaran IPS melalui implementasi pendekatan values clarification technique menunjukkan bahwa proses pembelajaran IPS lebih bisa meng aktifkan siswa dan siswa lebih banyak belajar tentang nilai-nilai baru seperti toleransi, kepedulian dan tanggung jawab selama pro ses pembelajaran maupun di luar proses pembelajaran. Hal ini ditunjukkan siswa pada saat berdoa sebelum dan sesudah belajar, mengucap salam dan berjabat tangan saat bertemu guru, tidak lagi mengganggu temannya pada saat belajar, siswa tidak lagi dipaksa guru untuk melaksanakan sholat dzuhur berjamaah. Dengan demikian metode cerita anak yang diterapkan memudahkan dalam mengklarifikasi nilai-nilai. Serta dapat mendorong siswa untuk berpikir, berdiskusi, memilih dan mempertimbangkan nilai dengan menjawab pertanyaan yang relevan dengan nilai-nilai tertentu untuk mengembangkan keterampilan siswa dalam melakukan proses menilai.

Proses pembelajaran IPS dengan menerapkan metode diskusi kelompok yang dipadukan dengan cerita anak, dapat mening katkan nilai toleransi, siswa bisa belajar menghargai pendapat temannya, mengambil keputusan secara berkelompok, melatih kerjasama sehingga siswa tidak lagi rebut membicarakan materi di luar pelajaran tetapi siswa berdiskusi tentang cerita yang diberikan guru. Selain itu peningkatan juga terjadi pada nilai kepedulian, siswa sudah bisa berbagi dengan temannya yang membutuhkan bantuan misalnya dengan meminjamkan alat tulis kepada temannya, program infak sudah bisa berjalan dengan baik. Selain itu, siswa mulai peduli terhadap kelas yang kotor, sehingga tanggung jawab masing-masing kelompok petugas piket sudah berjalan de ngan baik. Jadi metode yang diterapkan guru dapat membantu siswa dalam menentukan dan menerapkan nilai yang baik melalui diskusi kelompok yang dipadukan dengan cerita anak sehingga siswa dapat meningkatkan sikap saling menghargai teman yang sedang berbicara, peduli pada teman yang kesulitan dan menyelesaikan tugas dalam kelompok.

Proses pembelajaran IPS dengan menerapkan metode analisis kasus. Melalui pendekatan metode ini, siswa sudah berani mengungkapkan gagasan, pendapat, maupun perasaannya. Dengan cara ini siswa belajar menentukan nilai hidup secara benar dan jujur. Peningkatan perilaku ditunjukkan siswa saat menyelesaikan tugas dengan sungguh-sungguh dan mengumpulkan tugas tepat waktu, melaksanakan tugas piket sesuai jadwal yang ditetapkan, meminjamkan peralatan tulis pada teman yang membutuhkan, berani mengutarakan jawaban di depan teman-temannya, siswa tidak lagi malu untuk bertanya kepada guru. Metode yang diterapkan guru berhasil meningkatkan karakter siswa pada nilai toleransi pada sesama, peduli pada teman 
yang mengalami kesulitan dan tanggung jawab dalam menyelesaikan tugas baik individu maupun kelompok.

Dapat diambil kesimpulan bahwa siswa kelas V mampu melaksanakan tahapan VCT sampai pada tahap 3 yaitu berbuat, walaupun untuk melalui sampai pada tahap berbuat diperlukan proses yang tidak cepat. Proses penanaman nilai-nilai karakter sudah seharusnya tidak dikembangkan di dalam lingkup kelas saja tetapi di luar kelas, agar siswa mempunyai kesadaran untuk mena namkan nilai dan mampu melaksanakan nilai dalam kehidupan sehari-hari.

\section{SIMPULAN}

Berdasarkan dari data yang diperoleh dan hasil pengujian hipotesis, maka penelitian ini dapat disimpulkan sebagai berikut:

Implementasi Values Clarification Technique (VCT) dalam Pembelajaran IPS di SD Sekarsuli dapat ditempuh melalui metode tanya jawab, cerita anak secara konteks tual, analisis kasus (dilemma moral) yang disesuaikan dengan permasalahan siswa, serta diskusi kelompok untuk melatih kerja sama, saling menghargai serta menyelesaikan tugas secara bersama.

Hasil Implementasi Values Clarification Technique (VCT) dalam pembelajaran IPS dapat memunculkan perilaku positif siswa se perti aspek nilai taat beribadah, toleransi terhadap sesama, kepedulian terhadap teman yang kesulitan, dan tanggung jawab dalam menyelesaikan tugas tepat waktu baik individu maupun kelompok

\section{UCAPAN TERIMA KASIH}

Kami ucapkan terima kasih kepada Kepala Sekolah, guru dan siswa SD Sekarsuli, Banguntapan, Bantul, Yogyakarta yang telah membantu proses pelaksanaan penelitian ini sehingga peneliti dapat mengembangkan hasil penelitian menjadi sebuah karya ilmiah.

\section{DAFTAR PUSTAKA}

A. K. ,Ellis. 1997. Teaching and Learning Elementary Social Studies. Boston: Allyn \& bacon A Viacom Company.

Barth, James. L. 1990. Methods of Instruction in Social Studies Education. New York: University Press of America.

B. , Hall. 1973. Values Clarification as Learning Process. New York: Paulist Press.

Depdiknas. 2003. Undang-Undang RI Nomor 20, Tahun 2003, tentang Sistem Pendidikan Nasional.

Musfiroh, Tadkiratun. 2008. Character Building. Yogyakarta: Tiara Wacana.

S. , Nasution. 2006. Kurikulum dan Pengajaran. Jakarta: PT Bumi Aksara

Sanjaya, Wina. 2008. Strategi Pembelajaran Berorientasi Standar Proses Pendidikan. Jakarta. Kencana Media Group.

Sardjiyo. 2007. Pendidikan IPS di SD. Jakarta: Universitas Terbuka.

Simon, Sidney B. 1972. Values Clarification, A Handbook of Practical Strategies for Teachers and Students. New York: Hart Publising Company.

T.V, Savage dan D. G. Amstrong. 1996. Effective Teaching in Elementary Social Studies (Third Edition). New Jersey: Prentice Hall. 